PAWEE DUBER

Muzeum Józefa Piłsudskiego w Sulejówku Warsaw

\title{
THE LEADERSHIP OF THE SANACJA CAMP AND THE CONTROVERSY OVER THE FUTURE CONSTITUTION,
} 1928-1935

The coup d'état of May 1926 should be regarded as one of the most important events in the recent history of Poland. The seizure of power by Józef Piłsudski put an end to the period usually referred to as the 'era of parliamentary ascendancy'. ${ }^{1}$ One of the main goals of the political camp led by Marshal Piłsudski was to strengthen the executive prerogatives of the president by introducing far-reaching changes to the Constitution of 1921. The camp's leaders also stressed the need to cure all the ills plaguing the country's political life. ${ }^{2}$ For this reason, the regime that came to power in 1926 began to be called the 'Sanacja' (an elusive term best translated as 'moral improvement'). However, it should also be remembered that Piłsudski, in seizing almost complete control of Polish political life, did not have a clear-cut programme for rebuilding the foundations of political system. Work on this programme, undertaken long before the May Coup, continued for many years, revealing serious divergences of opinion among the Marshal's close associates. The most significant conflicts involved the attempts to give a new shape to the upper house of parliament, to determine the mutual relations between

${ }^{1}$ Janusz Pajewski, Budowa Drugiej Rzeczypospolitej 1918-1926, Kraków, 1995, p. 199. A historian known for being a Piłsudski adherent went so far as to use the term 'the period of the Sejm's omnipotence'. See Władysław Pobóg-Malinowski, Najnowsza historia polityczna Polski, 3 vols, Gdańsk, 1990, vol. 2: 1914-1939, p. 579.

${ }^{2}$ For more on the problem see Andrzej Friszke, O kształt niepodległej, Warsaw, 1989, pp. 227-29; Andrzej Garlicki, Od maja do Brześcia, Warsaw, 1981, p. 150. Among more recent works see Waldemar Paruch, Myśl polityczna obozu piłsudczykowskiego 1926-1939, Lublin, 2005, pp. 211-15. 
the executive and legislative branch of the state, and to elaborate the procedure for the election of the president.

It is possible to distinguish two phases in the controversy which, while concerning the new constitution, divided Piłsudski's adherents. The first, covering the period 1928-30, is connected with the rivalry between Kazimierz Bartel, five-times prime minister during the Sanacja era, and a group of Piłsudski's close associates called the 'Colonels'. The latter have often been perceived as the most authoritarian branch of the Sanacja camp. They were in charge of the Non-Party Block for Cooperation with the Government (BBWR) - a pro-government organization brought into being shortly before parliamentary elections held in $1928 .^{3}$

The conflict in question has already been covered by historians, ${ }^{4}$ but these authors have rarely focused their attention on the constitutional dimension of the problem. ${ }^{5}$ The second stage of the controversy came in the years 1931-35 and concerned the debates that culminated in the enactment of the April 1935 Constitution. The debates revealed a substantial disagreement among the 'Colonels'. However, it was only after Piłsudski's death on 12 May 1935 that this controversy became conspicuous. The Marshal's death, which came soon after he put his signature to the new constitution, forms the closing caesura of this article. It is also worth noting that the focus here is only on those who, in addition

${ }^{3}$ The author of a monograph on the political concepts of Piłsudski's supporters introduced a distinction between a 'group' and a 'circle' of Colonels. Among the former he included Walery Sławek, Kazimierz Świtalski, Janusz Jędrzejewicz and Aleksander Prystor. The 'circle' comprised all those who in the years 1930-35 were close to the circle of Colonels and played some role in political life of the Sanacja regime. Władysław T. Kulesza, Koncepcje ideowo-polityczne obozu rzadzacego $w$ Polsce $w$ latach 1926-1935, Wrocław, 1985, p. 118.

${ }^{4}$ Andrzej Ajnenkiel, Polska po przewrocie majowym. Zarys dziejów politycznych Polski 1926-1939, Warsaw, 1980, pp. 144-45, 174-75; Jerzy Marek Nowakowski, Walery Sławek (1879-1939). Zarys biografii politycznej, Warsaw, 1988, pp. 76-77, 93-94; Andrzej Chojnowski, Piłsudczycy u władzy. Dzieje Bezpartyjnego Bloku Współpracy z Rzadem, Wrocław, 1986, pp. 28-30, 108-09; Andrzej Garlicki, Piękne lata trzydzieste, Warsaw, 2008, pp. 82-84; Wiesław Władyka, Działalność polityczna polskich stronnictw konserwatywnych w latach 1926-1935, Wrocław, 1977, p. 161; Jan Kęsik, Zaufany Komendanta. Biografia polityczna Jana Henryka Józewskiego 1892-1981, Wrocław, 1995, pp. 42-44; Dorota Malczewska-Pawelec, Bogusław Miedziński (1891-1972). Polityk i publicysta, Łódź, 2002, p. 165; Marek Sioma, Sławoj Felicjan Składkowski (1885-1962). Żołnierz i polityk, Lublin, 2005, pp. 142, 175-76; Andrzej Krawczyk, 'Kazimierz Bartel, premier Rzeczypospolitej 15 V-4 VI 1926, 8 VI24 IX 1926, 27 IX-30 IX 1926, 27 IV 1928-13 IV 1929, 29 XII 1929-17 III 1930’, in Prezydenci i premierzy Drugiej Rzeczypospolitej, ed. Andrzej Chojnowski and Piotr Wróbel, Wrocław, 1992, p. 242; Ludwik Malinowski, Politycy Drugiej Rzeczypospolitej 1918-1939 (służba $i$ życie prywatne), 2 vols, Toruń, 1997, vol. 2, p. 13.

${ }^{5}$ There is a rather inadequate discussion of Bartel's political ideas in Kulesza, Koncepcje ideowo-polityczne, pp. 72-77. 
to being involved in this controversy, worked closely with Piłsudski. We do not take into account other groups within the broadly defined Sanacja camp, such as the conservatives or 'Naprawiacze' ('repairers') such as Jerzy Szurig, Wiktor Przedpełski and Tadeusz Katelbach.

In the summer of 1928 the BBWR stepped up its efforts to change the constitution. Following the proposal put forward by Walery Sławek - the BBWR's chairman and one of Piłsudski's closest friends - a special meeting was held with a view to discussing constitutional problems. Apart from politicians representing the Sanacja regime, the meeting attracted distinguished lawyers largely connected with conservative circles. Absent from the meeting was Kazimierz Bartel, the then prime minister, which clearly shows that he was not deeply involved in the attempts to modify the constitution. ${ }^{6}$ However, given his position, the BBWR's leadership kept Bartel informed of the progress made. Bearing witness to this is a surviving draft of the constitution presented to the Prime Minister for consultation with a note on the first page of the document: 'A copy for Prime Minister Kazimierz Bartel. The draft of the constitution prepared by the BBWR'. The prime minister was also asked to indicate the most significant propositions included in the project. The head of the cabinet must have analysed the draft in detail, for much of the surviving version of the typescript is underlined. ${ }^{7}$ This of course is insufficient to form a clear opinion about Bartel's view of the proposed changes. However, there survives another typescript containing general guidelines to be followed in the drawing up of the future constitution. It is neither dated nor signed. For this reason, it is not possible to say with absolute certainty by whom it was drawn up. But it is kept in the files of the Presidium of the Council of Ministers, among the same group of documents as the draft of the constitution prepared by the BBWR and reviewed by Bartel. ${ }^{8}$ Taken together, all of this seems to indicate that its author was Bartel himself. That this was the case is above all suggested by the views contained therein.

The first issue dealt with in the document concerns the election of the president. The head of state should be elected for a term of ten years by people of twenty-four years of age and above, who could read Polish. The

${ }^{6}$ Compare: Adam Piasecki, Sprawozdanie z ankiety przygotowawczej do reformy konstytucji odbytej $w$ dniach 30, 31 lipca i 1 sierpnia 1928 r.w Warszawie na zaproszenie pos. płk. Walerego Sławka Prezesa Klubu Bezpartyjnego Bloku Wspótpracy z Rządem pod przewodnictwem Pos. Prof. Wacława Makowskiego, Warsaw, 1928.

${ }^{7}$ Egzemplarz konstytucji, wniesiony przez BBWR pod obrady Sejmu w 1929 r., AAN, Prezydium Rady Ministrów, VI, sign. 5-2 II, fols 30-67.

${ }^{8}$ Zasady Zmiany Konstytucji, AAN, Prezydium Rady Ministrów, VI, sign. 5-2 II, fols 153-54. 
method of carrying out the election was complicated. Each commune was to elect 'primary voters' who, in turn, elected delegates. The latter were to form the National Assembly, which would meet in Warsaw to elect the president. Consisting of 444 deputies, a unicameral parliament was to be elected every five years in general, direct, secret and proportional elections. The right to vote was to be granted to everyone twenty-four years of age and above, while those who wanted to stand in the election had to be at least twenty-eight years old and have completed general education. ${ }^{9}$ The author of the project also proposed to create the Council of Laws (Rada Praw), to be made up of fifty members who had to be at least thirty-five years of age. They would be elected for a term of five years. Twenty-five members of this body would be appointed by the president from among people 'learned in the law and well-informed about economic life'. Eleven members of the Council would be elected by universities and four by polytechnics. Parliament was supposed to choose the rest - but from outside its own ranks. ${ }^{10}$ The fact that presidential nominees made up half of the members of the Council shows clearly that the body was entirely dependent on the head of state. Along this line, the project also proposed to arm the president with a veto by giving him the "right to hold over the publication of a bill passed by Parliament' when its passage was obtained 'with little or no regard for the opinion expressed by the majority of the Council of Laws'. If the president decided to exercise this right, then within six weeks the bill was referred back to the House where it could be carried through by a majority of eleven out of twenty. After that, the president was obliged to sign the bill into law. ${ }^{11}$ According to the project, the government would have a chancellor at its head, nominated for office by the president. The chancellor would be entrusted with the task of forming the cabinet - 'constitutionally accountable to the State Tribunal and parliamentarily accountable to the Sejm'. Interestingly, the Council of Ministers thus formed did not need to gain a seal of approval from parliament. The possibility of dismissing the government by parliament would arise only as a result of 'the rejection of the government's annual report by a majority of 245 deputies (absolute majority)'. The rejection of the government's budget proposal by the same majority was another way to oust the government. Individual ministers would not be held accountable to the sejm. Such accountability was to 'rest either with the chancellor in

\footnotetext{
${ }^{9}$ Ibid., fol. 153.

${ }^{10}$ Ibid.

${ }^{11}$ Ibid., fol. 154
} 
his capacity as the main representative of the government or with the government as a whole'. ${ }^{12}$

In reading these proposals, it is difficult to avoid the impression that the arrangements it contains were quite similar to those put forward by conservative circles. ${ }^{13}$ However, it was Bartel who proposed these procedures. That seems to be attested to not only by the passage advocating the idea of providing the prime minister with chancellor-like powers, but also by the interview Bartel gave to Kurier Wilenski, a daily newspaper published in Wilno (Vilnius). This interview was later also published in pamphlet form. In the preface to this publication, Bartel stressed the fact that it should be regarded as expressing a general criticism of the parliamentary system. In his opinion, the system was deeply flawed as it lacked 'organizational sense' and rested on 'contradictory assumptions'. ${ }^{14}$ In response to a question regarding the crisis of parliamentarianism in general, he remarked that complaints about the parliamentary system made themselves heard in countries in which such a system was already well-established. This was clearly indicative of the ills from which it suffered. In fact it seemed to have crisis at its very core. On the one hand, the principles underlying it made the formation of the government dependent on a parliamentary majority. On the other hand, parliament's basic role consisted in exercising control over the executive branch of the government. It was then clear that 'the very same parties that, holding a majority in the House of Representatives, are supposed to appoint the government and accept responsibility for its policy, are also supposed to control it. That is obvious nonsense'. This line of reasoning allowed Bartel to arrive at the conclusion that the cabinet should be appointed by the president and not by parliament. In his opinion, the practice prevalent in the period before May 1926 showed that in Poland the legislature had never been able to exercise effective control over the executive. ${ }^{15}$ In response to a question about parliament's control of the government, he said:

the government should be required to present to the Sejm an annual report on the whole of its activity. Such a report can serve as the basis

12 Ibid.

${ }^{13}$ This is clearly seen in the indirect way of electing the head of state as well as in the idea of establishing the Council of Laws which was supposed to become a kind of the Upper House of Parliament. Compare: Tomasz Sikorski, 'W kręgu państwa i władzy'. Koncepcje ustroju politycznego polskich konserwatystów (1926-1939), Torun, 2007, pp. 120-26, 273-89.

${ }^{14}$ Kazimierz Bartel, Niedomagania parlamentaryzmu. Wywiad z Prezesem Rady Ministrów Prof. Dr. Kazimierzem Bartlem ogłoszony w Kurierze Wileńskim z dn. 4 października 1928 r., Warsaw, 1928, p. 3.

${ }^{15}$ Ibid., pp. 5-7. 
for discussion [...] possessing characteristics of real critique and control. This is an ex-post control. [...] The future is to be discussed along with budget proposals which the government is also required to present to Parliament every year. Both discussions ought to be held apart [...].

Bartel accused the deputies of laziness, the source of which, in his opinion, lay in the corrupting principles on which the functioning of both houses of parliament was based. In formulating such a view, he relied, as he himself declared, on his own experience of parliamentary life. ${ }^{16} \mathrm{He}$ did not rule out the possibility of parliament dismissing the government. He added, however, that this

cannot be done in an irresponsible and insouciant way. The government which seriously treats its duties cannot become a plaything in the hands of political parties putting their own particular interests ahead of the vital interests of the whole state.

He unambiguously declared himself in favour of a 'chancellor system' in which the head of the government was appointed by, and answerable to, the head of state. The prime minister should also be given the freedom to choose individual ministers, none of whom, however, should be held accountable for the policy carried out by the government as a whole. Bartel also argued for an increase in the voting age from twenty-four to twenty-five. ${ }^{17}$

It is not difficult to see that the views articulated in the publication under discussion and the document mentioned previously are very similar. Noteworthy here is not only the fact that the head of government was supposed to exercise chancellor-like powers, but also that he depended on the president for his nomination..$^{18}$ Also worth mentioning is the question of parliamentary control of the government. Both the typescript providing the outline of the potential political system, and the interview for Kurier Wileński propose to deal with the problem in an almost identical way: both require the premier-chancellor to present an annual report on the government's activity. It is on this occasion that parliament is to be given a chance to oust the prime minister from office. Another opportunity to deprive the chief of government his power would arise only during a budget debate. Moreover, both the typescript and the interview contain a suggestion to raise the voting

${ }^{16}$ Ibid., pp. 7-8.

17 Ibid., pp. 8-10.

${ }^{18}$ Bartel referred to this issue also in 1933 in an interview with Bunt Młodych. In his opinion, such a solution was the best way in which to make the government work properly. 'Wywiad z Profesorem Kazimierzem Bartlem', Bunt Młodych, 1933, 38, p. 5. 
age from twenty-four to twenty-five. It can therefore be argued that in the interview in question, Bartel offered some general ideas on how to reform the political system. These ideas were presented in more detail in the typescript dealt with here, whether this was an earlier or a later document. It is interesting to note that the interview says nothing about establishing a Council of Laws. Bartel may have thought that it was too early to reveal this idea. He must have been aware of the fact that, while falling outside the framework of a classical form of parliamentary democracy, it was likely to elicit a critical reaction. Quite paradoxically, in imposing limitations on the legislature, his proposals went even further than those prepared by the BBWR and brought before parliament for debate. ${ }^{19}$ The BBWR's programme proposed to elect the president in a general election, granting the right to vote to everyone over twenty-four years of age, without, however, mentioning anything about the ability to read and write in Polish. The president was to be elected from two candidates - one suggested by the outgoing president and one proposed by both houses of parliament. While in agreement with Bartel's proposal in its suggestion to raise the voting age, the BBWR's proposals said nothing of the establishment of the Council of Laws dependent on the head of state. In contrast, Bartel proposed to create such an institution, half of whom were to be presidential nominees and, consequently, dependent on the president. The remaining members of the Council were to be appointed in a way that deprived citizens of any influence on its composition. Such a solution needs to be regarded as radically elitist. Its adoption may have been influenced by the fact that Bartel, a distinguished scholar connected with university circles, naturally wanted to reserve an important role for them. In the BBWR's programme the right to run for office was to be given to those of at least thirty years of age. Bartel wanted to lower this threshold by two years. However, he suggested a condition that those who wished to stand for election were required to have an elementary education - a condition which, given the realities of interwar Poland, may have been too difficult for many to fulfil. Also surprising is the extent to which Bartel wanted to restrict the legislature's traditional control of the executive. Allowed to evaluate the government's work only twice annually, the former actually lost control of the latter for the majority of the year. The BBWR's project offered no solution to this problem.

${ }^{19}$ For more on the project see: ‘Wniosek posła Walerego Sławka i kolegów z Klubu Bezpartyjnego Bloku Współpracy z Rządem w sprawie zmiany niektórych postanowień Ustawy Konstytucyjnej w trybie, przewidzianym dla jej rewizji', Sejm RP, Okres II, druk nr 444; Wacław Komarnicki, Ustrój państwowy Polski współczesnej. Geneza i system, Kraków, 2006, pp. 96-109. 
Instead, it only tightened the procedure used in the submission of a motion of no confidence against the government. The acceptance of the proposals put forward by Bartel had to result in the establishment of a duumvirate comprising the prime minister and the president, therefore leaving the opposition unable to exercise any influence on Polish political life. Thus the proposals offered by the Bartel, who was considered as a liberal, can be seen as even more authoritarian than those put forward by the BBWR. ${ }^{20}$

These concepts did not meet with the "Colonels" approval. This much is evident from the conversation Kazimierz Światalski - one of the leading politicians within this group - held with Wacław Bitner on 24 November 1929, that is, many months later. The conversation concerned possible ways of reforming the Polish political system. In referring to the possibility of establishing the chancellor system of government, Świtalski said that in his opinion

The Polish psyche makes it difficult to reconcile the position of the president [...] with one occupied by someone else who would be a real ruler and such would be the position of this premier-chancellor. The Polish psyche makes it necessary for power to be symbolically perceived by the people as united in one man. It cannot be divided between two persons. ${ }^{21}$

Given this opinion, it is hardly surprising that Bartel's proposals were left out of the project prepared by the BBWRs leadership. Bartel seems to have been offended by the omission. ${ }^{22}$

However, this failure did not discourage him from attempting to push through his reforms in defiance of the position adopted by the 'Colonels'. At the beginning of 1930, a few days after being reinstalled

${ }^{20}$ It is worth considering how far Bartel himself can be given credit for elaborating these concepts, and how far their elaboration can be ascribed to the influence of different theoreticians dealing with political systems. It is hard to resolve the issue unequivocally. However, there is no doubt that the idea of making the position of the head of the government strong and answerable to the president had appeared earlier. This is indicated by K. Korczewski's publication of 1926 in the pages of Droga. See: K. Korczewski, 'O stanowisko władzy w Polsce', Droga, 1926, 8, pp. 631-40. The proposals contained in the publication correspond with those put forward by Bartel in his constitutional reforms.

${ }^{21}$ Kazimierz Świtalski, Diariusz. Uzupełnienie z lat 1919-1932, Warszawa 2012, p. 96.

${ }^{22}$ Kazimierz Świtalski, Diariusz 1919-1935, Warsaw, 1992, s. 366. Analysing Bartel's proposals, it is difficult to agree with the opinion expressed by Władysław Sikorski who in a letter to Ignacy Paderewski called them compromising or conciliatory, saying that they were rejected as 'insufficient'. See: Archiwum polityczne Ignacego Paderewskiego, 5 vols, Wrocław and Warsaw, 1973-2001, vol. 3, ed. Halina Janowska and Czesław Madajczyk, 1974, p. 147. 
as prime minister, he discussed the question with Prince Janusz Radziwiłk, informing him that the government had not yet prepared the constitutional reform programme. ${ }^{23}$ On 11 January 1930 he appeared at the meeting of parliament's Constitution Committee in order to show that he was interested in constitutional problems. ${ }^{24}$ There is evidence to suggest that his appearance there was not merely an insignificant or propagandistic gesture. In giving an account of the meeting, Stanisław Cat-Mackiewicz made it clear that the leadership of the Sanacja camp had produced two plans for constitutional reform. According to Cat's account, Feliks Dutkiewicz, the minister of justice, was to say that both 'his and Bartel's views on the changes to be introduced in the constitution differ from those held by the BBWR's members engaged in the task of carrying out its revision.' However, 'the opposition betrayed no willingness to favour either Colonel Sławek's proposal or that of Premier Bartel'. ${ }^{25}$ Moreover, on 11 March 1930 the head of the government decided to set up a special committee made up of constitutional experts. Its first meeting was to take place a week later. ${ }^{26}$ Andrzej Chojnowski is correct both in pointing to Bartel's conversation with Radziwiłl and claiming that the former entertained the idea of introducing his own bill of constitutional amendments. ${ }^{27}$ It is hardly surprising then that during the meeting of the Preservation Committee (Komitet Zachowawczy) Radziwiłł informed those in attendance of serious conflicts within the Sanacja leadership. In recounting his conversation with

${ }^{23}$ Bogusław Gałka, Ziemianie w parlamencie II Rzeczypospolitej, Toruń, 2000, p. 99.

24 'Rozpoczęcie pracy nad rewizją konstytucji. Pierwsze dwa głosy w debacie na komisji konstytucyjnej', Gazeta Polska, no.11,12 I 1930, p. 2; Stanisław Mackiewicz, 'Czterdzieści jeden posiedzeń Komisji Konstytucyjnej', Przegląd Współczesny, 37, 1931, pp. 76-77. See also: idem, Historia Polski od 11 listopada 1918 r. do 5 lipca 1945 r., London, s.a., p. 203. During the meeting of the Constitution Committee the deputy Mieczysław Niedziałkowski delivered a paper expressing the following opinion: 'The Prime Minister Bartel advocates a "chancellor system". In a way we already had such a system in Poland. Władysław Grabski was such a kind of a chancellor and it is difficult to imagine that a prime minister can hold a greater power over his ministers than that which, although ungrounded in the constitution, was held by Grabski', Mieczysław Niedziałkowski o demokracji i parlamentaryzmie, ed. Michał Śliwa, Warsaw, 1996, p. 145.

${ }^{25}$ Mackiewicz, 'Czterdzieści jeden posiedzeń', pp. 76-77.

${ }^{26}$ The committee comprised the following: Zygmunt Cybichowski, Antoni Peretiatkowicz, Michał Rostworowski, Jan Kopczyński, Władysław Kuczyński and Jan Kanty Piętak. Koncept pisma z 11 marca 1930 r. informującego o powołaniu Komisji rzeczoznawców konstytucyjnych oraz mianowaniu jej członków, AAN, Prezydium Rady Ministrów, VI, sign. 5-2 I, fols 13,18. The decision to set up the committee was made personally by the prime minister a few days earlier. Those who sat on the committee were supposed to express opinions on 'political issues relating to the revision of the constitution' See: 'Z Prezydium Rady Ministrów', Monitor Polski, no. 60, 13 March 1929, p. 2.

${ }^{27}$ Chojnowski, Piłsudczycy u władzy, pp. 148-49. 
Piłsudski, he said that he was under the impression that "when it comes to the relations with the sejm it is Colonel Sławek and not Bartel who enjoys the Marshal's confidence'. For Sławek, unlike Bartel, 'is prepared to strictly follow Piłsudski's instructions'. ${ }^{28}$ This opinion explains why political concepts promoted by Bartel, five-times prime minister, could never materialize. He lacked sufficient political support to implement them. In the first place, of course, Bartel's proposals failed to gain acceptance from Piłsudski who remained the most important decision maker in Poland's post-May political landscape.

Bartel, after resigning in March 1930, was never again appointed to any important position. In the autumn of the same year, following the government's crackdown on the opposition and the victorious elections in which the BBWR won the majority of seats in both houses of parliament, it was the 'Colonels' who began to dominate the political life of the Second Republic. Unsurprisingly, it was their project, brought before parliament in unaltered form on 6 February 1931, which became the basis for further efforts to reform the political system. ${ }^{29}$ Soon the programme was referred to the parliamentary committee that began work on the new constitution. ${ }^{30}$ This work ran parallel to that carried out in the circle of Piłsudski's close associates who, as it turned out, were divided on how to reform the political system in Poland. The divisions within the group are reflected in the discussions that took place during the conference on constitutional issues called by Sławek on 20 June 1932. Lasting a few days, the conference was attended by leading representatives of the 'Colonels' group, as well as by other people connected with it. It is advisable to take a closer look at those discussions. They show that as early as 1931 the leading members of the group in question were deeply divided on a variety of issues concerning Poland's political system.

The conference dealt mainly with the method of electing the president. Stanisław Car was the first to address the meeting. He came up with the idea of a 'limited plebiscite'. It would consist of voting for one of the two candidates - one appointed by the National Assembly and one proposed by the outgoing president. However, Car argued that even such a plebiscite might be either 'unnecessary or undesirable' and that is why it should not be made an obligatory form of electing the head of state.

28 'Projekt protokołu posiedzenia Komitetu Zachowawczego w dniu 7 marca 1930', State Archive in Kraków (APK), Archiwum Dzikowskich z Tarnowa, sign. 700, fol. 123.

${ }^{29}$ Sprawozdanie stenograficzne z 10 posiedzenia Sejmu, 6 II 1931, 1. X/53; “Wniosek posłów z Klubu Bezpartyjnego Bloku Współpracy z Rządem z 6 lutego 1931 roku w sprawie zmiany Konstytucji', Sejm RP, Okres III, druk nr 111.

${ }^{30}$ Chojnowski, Piłsudczycy u władzy, pp. 188-89. 
The decision to hold a plebiscite was to be left to the outgoing president. Among other proposals concerning the election of the president was that put forward by Adam Skwarczyński. In his opinion, the president should be elected by the Assembly of Electors which one might liken to a conclave. The idea of a plebiscite-like election also failed to gain the support of Ignacy Matuszewski. However, Matuszewski contended that a compromise version put forward by Car seemed best suited to Poland's specific conditions. The meeting was also addressed by Świtalski who, unlike those who spoke before him, opted for general elections. In his opinion, the president, when elected by popular vote, 'receives a moral legitimacy that allows him to claim that his authority is derived directly from the will of the people'. He was of the opinion that with nominations for public office it was well-advised to defer to 'the instinct of the masses' which, although it could misjudge someone's intellectual ability, was unlikely to be mistaken in evaluating someone's moral value. He also added that it was necessary to sustain this form of election in order to avoid coup d'états and political upheavals. Consequently, he came out against the proposals presented by Skwarczyński. Skwarczyński's electors, he argued, are likely to turn out 'to be the same representatives of the people, put forward by politicians, who usually end up embroiled in a maelstrom of intrigue'. This, he remarked, was likely to be followed by charges of electoral malpractice. As a result, the president, perceived as "having been chosen by a "clique", would suffer serious damage to his reputation. Sławek in turn, while postponing the discussion of this problem until the next meeting, asked those in attendance to consider the idea of having 'the president elected by other candidates for presiden$c y$, those who will manage to get a given amount of the national vote'. ${ }^{31}$

Talks about the election of the president continued on the following day. Wojciech Stpiczyński voiced fears that the procedure suggested by Car would be likely to result in the 'emergence of two kinds of president: one chosen by plebiscite and one elected by the National Assembly. This in turn was likely to have the effect of undermining the authority of the president of the second kind'. The idea of electing the president by popular vote was definitely rejected by Janusz Jędrzejewicz, Skwarczyński, and Jan Piłsudski. Most participants at the conference supported the proposals put forward

31 'Protokół nr 1 konferencji u Prezesa Płk. Sławka w dn. 20 czerwca 1932 r. w sprawie zmiany Konstytucji', AAN, BBWR, sign. 77, fols 18-20. In light of the discussion it is difficult to understand the opinion expressed by Janusz Faryś, claiming that Piłsudski's supporters, while clearly advocating the idea of strengthening the prerogatives of the president, maintained that the head of state should be elected by popular vote. Janusz Faryś, Piłsudski i piłsudczycy. Z dziejów koncepcji polityczno-ustrojowej (1918-1939), Szczecin, 1991, p. 106. 
by Car. Some, for example Tadeusz Schaetzel, advocated a modification of Car's proposals presented by Wacław Makowski. Makowski, to even a greater extent than Car, made the conduct of a plebiscite dependent on the decision of the outgoing president. A modified version of Car's proposals was as follows:

The National Assembly elects the president of the Polish Republic by an absolute majority of its votes. If the outgoing president refuses to accept this choice, he puts forward his own candidate and then the next president is to be elected from among the two candidates by means of plebiscite.

However, Świtalski decided to support the earlier version of this project, finding it flexible and 'well suited to Polish conditions'. At the same time, unwilling to believe in the possibility of recruiting real elites, he called the programme presented by Skwarczyński a 'lottery'. The discussion was traditionally concluded by Sławek who posed a surprising question. He asked others whether - leaving aside the present circumstances in which such a solution was ruled out - one should not consider the idea of establishing in Poland a monarchy. ${ }^{32}$

The question of how to elect the president was also dealt with on 22 June 1932. In referring to the question put by Sławek the previous day, Stpiczyński said that, given the existing circumstances, the establishment of a monarchy would encounter serious difficulties. But he added that he would not be opposed to the idea of introducing a lifetime presidency, with each outgoing president designating his successor. However, this idea could be implemented only on the condition that Piłsudski was the first to take the office. He also did not reject the proposal brought forward by Makowski. But the latter's proposal, argued Stpiczyński, could only be implemented if Piłsudski refused to take the office. The idea of establishing a monarchy elicited no positive response from the meeting. Bohdan Podoski and Leon Kozłowski were the only people willing to take it into consideration. Podoski said that 'the Republic has failed to fulfil hopes set on it'. It was rejected by Bolesław Wieniawa-Długoszowski, Edward Rydz-Śmigły, Schaetzel, Matuszewski and Świtalski. Świtalski observed that in

32 'Protokół nr 2 konferencji u Prezesa Płk. Sławka w dn. 21 czerwca 1932 r. w sprawie zmiany Konstytucji', AAN, BBWR, 77, fols 21-26. Some historians argue that Sławek actually considered the possibility of introducing such a system in Poland. See Jan Borkowski, 'Piłsudczykowska koncepcja państwa', DN, 14, 1982, 1-4, p. 110. However, it seems that one should not attach too great an importance to such declarations. The conference dealing with constitutional issues clearly shows that the BBWR's head considered this idea in theoretical terms only. 
Poland 'monarchy could rest only on the support of the army and the peasantry. The latter, however, are not too reliable as the situation in Spain clearly shows'. In his opinion, the introduction of a monarchy was likely to result in the undermining of the strength of the executive, since it was difficult to imagine that the monarch might be granted greater powers than those conferred on the president. It is also worth noting that Świtalski, unlike others, endorsed Car's original proposal, rejecting Makowski's modifications. Consequently, more than any other participant at the conference, he took into account the possibility of electing the president by popular vote. It was Car who concluded the discussion by observing that the form of government is of secondary importance, for both monarchy and republic need to be based on a strong executive. ${ }^{33}$

Another meeting, held on 24 June 1932, was devoted to the election of senators and to the prerogatives they should be granted. A point of departure for the discussion was again provided by Car who declared himself against transforming the senate into a 'chamber of professions' or a 'chamber of commerce'. Instead, while proposing to leave intact the legal procedure used in the election of the upper house of the Polish parliament, he came up with the idea of fifty-five presidential nominees who were supposed to join the existing group of 111 senators. The senate, armed with the right of legislative initiative, 'should also be given more power in the field of enacting new laws'. This proposal met with a negative response and the only person prepared to support it was Matuszewski, in spite of the fact that, in his opinion, it gave no guarantee that a parliamentary majority would be formed by deputies of Polish nationality. It was also clear that the position of the senators to be nominated by the president was inherently weak. Therefore, Matuszewski proposed to increase the number of senators and extend the term of presidential nominees to fifteen years. However, most voiced the opinion that the senate should clearly distinguish itself from the lower house both in the procedure used in the election of its members as well as in the extent of its powers. Many stressed the need to reserve some senate seats for - besides presidential nominees representatives of local government. An interesting idea was presented by Makowski who opted for dividing the senate into three committees, including a legal one, with senators recruited from experts in various fields. Against this background stood out the proposals offered by Świtalski who saw the senate as an 'anachronism remaining from the period of the battles waged in the name of the people's rights, the result of tradition and

33 'Protokół nr 3 konferencji u Prezesa Płk. Sławka w dn. 22 czerwca 1932 r. w sprawie zmiany Konstytucji', AAN, BBWR, sign. 77, fols 27-30. 
political rhetoric'. The only advantage of having a senate lay, in his opinion, in the fact that it 'entails technical breaks in the legislative process, thus making the work of the government sometimes easier'. He also expressed a distrust of nominees, since 'in difficult situations they are the first to fail'. In fact, he argued against any experiments in this field, stressing the fact that the idea of transforming the senate into a chamber of professions, although in fashion, has nowhere been tried out'. ${ }^{34}$

The discussion concerning the upper house of parliament was continued three days later, on 27 June. Noteworthy is the opinion articulated by Podoski who, while presenting the problem against a wide historical background, found the transformation of the senate into a chamber of professions impossible to realize. In the discussion, an opposing view was offered by Stpiczyński, Makowski defended his own project, which he had presented during the previous meeting, and Świtalski decided to endorse Car's proposal, convinced that - in comparison with other projects - it entailed the smallest changes in the present system. He also supported Podoski when he observed that the transformation of the senate into a chamber of professions would force the authors of the new constitution to put it on an equal footing with the lower house. This, however, was not advisable, since these "professional experts have never received a parliamentary education which allows one to develop a skill of reaching acceptable compromises'. He also noted that Makowski's proposal was likely to turn the senate into an 'arena of intellectual showmanship which - because of the diversity of its composition would be either unable, just like a chamber of professions, to do any good work or, just like the present Senate, would break up into political clubs'. In conclusion, Świtalski observed that the adoption of the new constitution was needed to strengthen the executive, and the transformation of one of the houses of parliament into a chamber of professions would be a step in the opposite direction. Car's proposals also gained approval from the Marshal's brother, Jan Piłsudski. ${ }^{35}$

This brief discussion of the debate shows that the search for the best form of political system engendered a great variety of plans and ideas. It

34 'Protokół nr 4 konferencji u Prezesa Płk Sławka w dn. 24 czerwca 1932 r. w sprawie zmiany Konstytucji', AAN, BBWR, sign. 77, fols 31-36. Świtalski's opinions on the senate were not shared by Marshal Piłsudski's other followers who opted for maintaining a bicameral parliament. See: Waldemar Paruch, 'Parlament w państwie autorytarnym. Rozważania o myśli politycznej Józefa Piłsudskiego (1926-1935)’, in Józef Piłsudski a parlamentaryzm polski, ed. Arkadiusz Adamczyk, Warsaw and Bełchatów, 2009, pp. 21-24.

35 'Protokół nr 5 konferencji u Prezesa Płk Sławka w dn. 27 czerwca 1932 r. w sprawie zmiany Konstytucji', AAN, BBWR, sign. 77, fols 37-40. 
needs to be remembered that it was not conducted in isolation from tendencies across Europe to abandon democratic processes. Furthermore, Piłsudski's supporters, involved in the elaboration of a new political system, came under the influence of conservative circles whose political outlook was inspired by Italian fascism. ${ }^{36}$ However, one should also remember that these attempts at constitutional reform aimed to create a Polish variant of authoritarianism - one congruent with the political reality of the Second Republic. ${ }^{37}$ The analysis of the problem leads one to draw other notable conclusions. For instance, the 'Colonels', although often portrayed as holding similar views on how to run the government, were actually divided on a variety of important issues.

Interesting conclusions were also drawn from the conference by Jerzy Marek Nowakowski who divided its participants into two groups. The first, more pragmatic, group comprised Świtalski, whom Nowakowski described as the most liberal-minded among the participants, Matuszewski and Bogusław Miedziński. The second group, referred to as dogmatists, included Podoski, Kozłowski and Sławek. ${ }^{38}$ It has been correctly observed that the rupture within the Sanacja camp after Piłsudski's death ran along this line. However, it is difficult to agree with Nowakowski that the 'dogmatists' aimed to 'infuse social consciousness with the spirit of solidarity' while the 'pragmatists' strove only to remain in power. Both this conference, organized in secret, as well as a long-running dispute between Świtalski and Sławek indicate that this opinion is over-simplified. ${ }^{39}$ Almost one year earlier, in conversation with Piłsudski on 31 August 1931, both politicians touched on the subject of the election of the head of state.

${ }^{36}$ Krzysztof Kawalec, Spadkobiercy niepokornych. Dzieje polskiej myśli politycznej 1918-1939, Wrocław, 2000, p. 149.

${ }^{37}$ For more on the problem see Paruch, Myśl polityczna,pp. 244-63.

${ }^{38}$ Janusz Mierzwa disagrees with this view, saying that it is justified only in relation to Miedziński. Mierzwa argues that 'it would be better to categorize the Piłsudski adherents according to political views. [...] Koc and Matuszewski held the most right-wing views among all the Colonels'. Sławek, Prystor and Jędrzejewicz who in the last years of the Second Republic maintained close contacts with the former comrades from the PPS were placed at the opposite end of the political spectrum. Janusz Mierzwa, Pułkownik Adam Koc. Biografia polityczna, Kraków, 2006, p. 157. It seems that the classification offered by Nowakowski is more accurate, for it is difficult to understand on what basis one could consider Sławek as left-wing. His conception of the senate's electoral arrangements was extremely elitist. It needs to be remembered that such generalizations about everyone belonging to the group in question always simplify reality, regardless of the fact that the socialist past of the politicians mentioned by Mierzwa must have influenced their political outlook. Compare: Jerzy Gołębiowski, Spór o etatyzm wewnątrz obozu sanacyjnego w latach 1926-1939, Kraków, 1978, p. 82.

${ }^{39}$ Jerzy Marek Nowakowski, 'Konferencja konstytucyjna z czerwca 1932. U źródeł rozbicia grupy pułkowników’, SH, 25, 1982,3/4, pp. 446-47. 
Świtalski stressed that the problem caused much controversy, for there were fears that the office of president, whose power was to be considerably increased by the new constitution, might, regardless of the method of election, fall into the wrong hands. He also articulated the view that in his opinion 'one had nothing to fear from a plebiscite' and that he was prepared to accede to such a solution. Sławek, 'too scornful of election in general', was obviously dissatisfied with the fact that Piłsudski agreed with Świtalski. The Marshal also criticized the idea of a president whose term was to last longer than ten years, since 'no one is able to exercise public office for so long in good shape'. ${ }^{40}$ In reality, the political battle waged within the leadership of the Sanacja regime concerned the extent to which the new constitution was supposed to change the existing system. Świtalski, like many other supporters of Józef Piłsudski, advocated strengthening the president's authority. However, convinced that reform had to be based on proven solutions, he was opposed to carrying out the bold experiments favoured by Sławek and his associates. The controversy presented above, while deepening divisions in the circle of Marshal Piłsudski's close associates, forms an important episode in the history of political thought of the group he led.

Drawing on theoretical work carried out by the regime's leading lawyers and politicians, Car and Podoski were able to elaborate the final programme for constitutional reform. In the summer of 1933 they went to Spała at the president's special invitation. There they spent the whole month completing the project. ${ }^{41}$ It was then referred to the BBWR's Constitutional Group which held as many as twelve meetings between September and December of the same year, dealing with what was essentially the completed plan for constitutional reform. ${ }^{42}$ Podoski later recalled that in the autumn of 1933, the project was also discussed by 'the Assembly of Tenants' (an informal group comprising the incumbent prime minister and his predecessors) which presented their opinions to Car at these informal meetings. They complained that the project 'veered too far away from classical canons in abandoning Montesquieu's principle of separation of powers by concentrating undivided state authority in the person of the President of the Polish Republic'. ${ }^{43}$ Podoski counted Świtalski and Prystor among the main critics of the project, which allows us to assume that most

\footnotetext{
40 Świtalski, Diariusz 1919-1935, pp. 620-21.

${ }^{41}$ Bohdan Podoski, 'Prace nad konstytucją kwietniową', Niepodległość, 12, 1979, p. 189.

${ }^{42}$ Chojnowski, Piłsudczycy u władzy, pp. 188-90.

${ }^{43}$ Podoski, 'Prace', p. 190.
} 
opinions articulated during these secret meetings must have come from them. This fact is worth noting, since, according to Podoski, Sławek

called the combined meeting of the BBWR's constitutional groups as well as those of the Sejm and Senate - the latter included all the members of Sejm and Senate Constitution Committees - and presented them with the opinions and suggestions of the 'Tenants' without, however, specifying the authors of these opinions. In the discussion which ensued, the vast majority declared themselves in favour of leaving the existing project unchanged. This decided its fate. ${ }^{44}$

If this information is true, then it is further proof that there were serious divisions within the leadership of the Sanacja regime, especially between Świtalski and Sławek. For the time being, however, they posed no threat to the camp's internal unity; for the ideas promoted by the BBWR's head - most conspicuously exemplified in the conception of the so-called Legion of Notables, included in the project and constituting an extremely elitist way of electing members of the upper house of parliament - enjoyed the support of most of its members. ${ }^{45}$ The controversy surrounding the constitution came up at the plenary session of the sejm. Parliament discussed the Constitutional Committee's report on the BBWR's motion relating to the change of the constitution. Car proposed to accept the constitutional theses, examined by the afore-mentioned Committee, as the basis for the new constitution. This proposal gained approval from the Sanacja leadership who, taking advantage of the absence of the members of the opposition parties, secured the adoption of the new constitution. However, the new constitution was adopted in contravention of the article 125 of the old constitution. According to the article, the constitution could only be changed by a majority of two-thirds, and if at least half the members were in attendance. Moreover, the article required the motion to change the constitution to be signed by at least a quarter of the

${ }^{44}$ A few days after the meeting, Sławek was to request Car to translate the conceptual work into constitutional theses, hoping that at least a part of the opposition would change its attitude towards the plans for the new constitution. See: ibid.,pp.190-91.

${ }^{45}$ For more on the project of the Statute of Citizen's Cadre which finally assumed the form of the Legion of Notables see: 'Statut Kadry Obywatelskiej', AAN, BBWR, sign. 89, fols 1-8; 'Statut Legionu Zasłużonych', ibid., fols 23-29; 'Statut Projekt Legionu Zasłużonych', in Kazimierz Władysław Kumaniecki, Ustrój polityczny Polski. Konstytucja kwietniowa i system wyborczy (sejmowy, senacki, prezydencki). Tekst i studium, Kraków, 1937, pp. 125-28. See also Komarnicki, Ustrój państwowy, pp. 151-54; Kulesza, Koncepcje ideowo-polityczne, pp. 138-43; Chojnowski, Piłsudczycy u władzy, pp. 214-15; Nowakowski, Walery Sławek, pp. 119-23. 
members of the house and be announced fifteen days in advance. ${ }^{46}$ It is not inconceivable that this was the reason why the speaker of the sejm, Świtalski, protested against the strategy employed by the Sanacja leadership. However, he failed to persuade his associates to abandon the new constitution because of a violation of the existing law. ${ }^{47} \mathrm{~A}$ few days later it turned out that the line of action taken by the Sanacja leaders did not gain acceptance from Piłsudski himself, as he disapproved of the passing of a crucial legal act by 'wit and trick'. The Marshal, in Świtalski's presence and to his satisfaction, ordered Sławek to refer the constitutional reforms back to parliament. Moreover, Piłsudski also took a negative view of the idea of the so-called Legion of Notables put forward by the BBWR's head. ${ }^{48}$ His opposition resulted in the exclusion of this idea from lengthy deliberations concerning the reform programme. ${ }^{49}$ The new constitution was finally adopted during the plenary session of parliament on 23 March $1935 .^{50}$ Its adoption should be regarded as the culmination of the Sanacja's long efforts, riven by conflicts and controversy, to reform the political system.

The reform of the Polish political system under discussion was to be complemented with Sławek's concept of the so-called General Social Organization. However, it did not obtain the approval of other politicians who counted among the late Marshal's most trusted associates. Sławek's removal from power decided its fate. ${ }^{51}$ Conflicts within the circle of the

${ }^{46}$ Władysław Rostocki, Pięćdziesiąt pięć lat mocy obowiązującej Konstytucji Kwietniowej. Ustrój władzy państwowej w ustawie zasadniczej i praktyce, Lublin, 2002, p. 39.

${ }^{47}$ Podoski, 'Prace', p. 192. For more on the problem see also: Paweł Duber, 'Nieznana relacja na temat ostatniego etapu pracy nad uchwaleniem konstytucji kwietniowej (1934-1935)', Niepodległość, 59, 2010, pp. 119-26.

48 Świtalski, Diariusz 1919-1935, pp. 653-55.

${ }^{49}$ On 29 June 1934, with work on the modified constitutional project already under way, Sławek officially backed out of the idea of the Legion of Notables. Consequently, a member of the Senate Constitution Committee, Wojciech Rostworowski, 'removed the respective fragment from the project, leaving the article generally invoking the idea of merit'. See Kulesza, Koncepcje ideowo-polityczne, pp. 143, 173. Compare: Andrzej Ajnenkiel, Konstytucje Polski w rozwoju dziejowym 1791-1997, Warsaw, 2001, pp. 210-11.

50 This time, too, the session bent the rules, since the meeting room during this plenary session was filled to the brim and Sanacja did not have the necessary two-thirds majority of the votes to pass the amendments to the senate. Ajnenkiel, Konstytucje Polski, p. 213.

51 The proposal for the General Social Organization, along with wide commentaries, was published by Andrzej Chojnowski, see: Andrzej Chojnowski, 'Utopia utracona Walerego Sławka. Projekt Powszechnej Organizacji Społecznej', PH, 80, 1989, 2, pp.353-65. For more on the problem see also: Jan Hoppe, Wspomnienia, przyczynki, refleksje, London, 1972, pp. 144-70; Nowakowski, Walery Sławek, pp. 144-51. 
Piłsudski supporters brought about a reshuffle in the Sanacja leadership, resulting in the disintegration of the whole camp, with many leading 'Colonels' pushed to the margins of political life. This of course was not followed by a political void; the BBWR was dissolved and in its place there emerged the two rival political centres, one headed by President Ignacy Mościcki and one led by the General Inspector of the Armed Forces, Edward Rydz-Śmigły. ${ }^{52}$ This constellation continued to exist until the outbreak of the Second World War put an end to the thirteen-year rule of the Sanacja regime in Poland. In exile, under the new circumstances, the Sanacja camp underwent further changes. In 1945, with Poland in the Soviet sphere of influence, the political ideas discussed above, along with the controversy they provoked, entered the history of Polish political thought.

(Translated by Artur Mękarski)

\section{Summary}

In seizing almost complete control of Polish political life, Piłsudski did not have a clear-cut programme for rebuilding the foundations of political system. Work on this programme, undertaken long before the May Coup, continued for many years, revealing serious divergences of opinion among the Marshal's close associates. The most significant conflicts involved the attempts to give a new shape to the upper house of parliament, to determine the mutual relations between the executive and legislative branch of the state, and to elaborate the procedure for the election of the president.

It is possible to distinguish two phases in the controversy which divided Piłsudski's adherents. The first, covering the period 1928-30, is connected with the rivalry between Kazimierz Bartel, five-times prime minister during the Sanacja era, and a group of Piłsudski's close associates called the 'Colonels'. As it turns out, Bartel went even further in his attempts to impose limitations on parliamentary democracy than the Colonels. However, his proposals failed to receive approval from Piłsudski, and Bartel himself had to retire from public life. The second phase of the aforementioned controversy came in the years 1931-35 and involved deliberations that culminated in the enactment of the April Constitution. Divergences of opinion revealed in the course of these discussions were a factor that accelerated the decomposition of Pisudski's camp after his death.

(Translated by Artur Mękarski)

${ }^{52}$ For more on the issue see: Jerzy Marek Nowakowski, 'Rozpad grupy pułkowników. Pierwsza faza dekompozycji sanacji', SH, 31, 1988, 1; Janusz Faryś, ‘Dekompozycja ideowa piłsudczyków 1935-1939', Przegląd Zachodni, 3, 1988, 3; Paweł Duber, 'Działalność Kazimierza Świtalskiego w pierwszym okresie dekompozycji obozu sanacyjnego (maj 1935-kwiecień 1936)', Niepodległość, 57, 2007, pp. 52-94. 